\title{
Pertanggungjawaban Hukum Pelaku Eksploitasi Seksual Pada Anak Melalui Internet
}

\author{
Twenty Purandari \\ twentyfender20@gmail.com \\ Universitas Airlangga
}

\begin{abstract}
Sexual Exploitation of Children is a extra ordinary crime and therefore violators or sexual criminal must be punished. Legal protection and law enforcement efforts in this case is needed to get mutual attention because the issue of sexual exploitation of children is currently very worrying problem and has not been resolved properly and even tends to be more widespread since the use of information and communication media through the internet. It is widespread in all levels of society. It need more legal rules and community participation to anticipate. The issue of sexual exploitation of children is included in the category of crimes against humanity which need to be prevented and abolished. Apart from violating the law, this exploitation violates the Convention on the Rights of the Child (CRC), which is also contrary to religious and cultural norms. That every child while in the care of parents, law enforcer, or any other party responsible for care, has the right to be protected from the treatment of exploitation both economically and sexually. But in fact there are still frequent practices of exploitation of children, especially in the increasingly sophisticated internet-based information and communication era like today, so that new kinds or form also emerge and the rule of law is required to be able to overcome the development of this problem. On this side, this normative juridical research is emphasized. This research is using statue approach and conceptual approach, to explane and to solve the problem.
\end{abstract}

Keywords: Sexual Exploitation of Children; Internet Media; Legal Sanctions.

\begin{abstract}
Abstrak
Eksploitasi seksual terhadap anak merupakan bentuk pelanggaran mendasar terhadap hak-hak anak dan oleh karena itu para pelakunya harus mendapatkan sanksi pidana yang setimpal. Upaya perlindungan hukum dan penegakan hukum dalam kasus ini perlu mendapatkan perhatian bersama karena persoalan eksploitasi seksual terhadap anak saat ini merupakan masalah yang begitu memprihatinkan dan masih belum terselesaikan dengan baik bahkan cenderung makin mewabah sejak penggunaan media informasi dan komunikasi melalui internet marak di seluruh lapisan masyarakat. Perlu aturan hukum yang lebih mengatasi dan peran serta masyarakat untuk antisipasi. Persoalan eksploitasi seksual terhadap anak hingga dimasukkan dalam kategori kejahatan kemanusiaan yang harus dicegah dan dihapuskan. Eksploitasi seksual terhadap anak ini selain merupakan perbuatan melanggar hukum, melanggar Konvensi Hak Anak (KHA), juga bertentangan dengan norma agama dan budaya. Bahwa setiap anak berhak mendapatkan perlindungan dari segala bentuk perlakuan eksploitasi baik secara ekonomi dan/atau seksual selama anak dalam pengasuhan orang tua, wali, atau pihak lain manapun yang bertanggung jawab atas pengasuhan. Namun nyatanya sampai saat ini masih sering terjadi praktek eksploitasi terhadap anak khususnya eksploitasi seksual, terlebih di era informasi dan komunikasi yang makin canggih berbasis internet seperti saat ini, sehingga modusmodus baru para pelaku eksploitasi seksual terhadap anak pun muncul dan aturan hukum pun dituntut untuk dapat mengatasi perkembangan persoalan ini. Pada sisi inilah penelitian yuridis normatif ini ditekankan dengan pendekatan masalah secara statue approach dan conceptual approach, penelitian ini diharapkan dapat mengurai permasalahan.
\end{abstract}

Kata Kunci: Eksploitasi Seksual Anak; Media Internet; Sanksi Hukum. 


\section{Pendahuluan}

Masyarakat dalam perubahan peradaban dari waktu ke waktu menghendaki adanya peningkatan taraf hidup. Ketika memasuki masa era globalisasi menunjukkan banyak kemajuan teknologi informasi yang telah mengubah perilaku masyarakat dan peradaban manusia secara global menjadi masyarakat modern yang berbasis internet. Di samping itu, perkembangan teknologi informasi telah menyebabkan dunia menjadi tanpa batas dan menyebabkan perubahan struktur sosial masyarakat yang secara signifikan berlangsung dengan cepat. Teknologi Informasi memberikan kontribusi yang sangat besar bagi peningkatan kesejahteraan, kemajuan dan peradaban manusia. ${ }^{1}$

Internet (interconnection-networking) yaitu jaringan komputer yang saling terhubung dengan menggunakan sistem Transmission Control Protocol (TCP) / Internet Protocol Suite (IP) untuk melayani seluruh pengguna di dunia. Melalui internet jutaan orang di seluruh dunia dapat terhubung dengan memanfaatkan ruang informasi dan komunikasi dalam dunia maya yang tanpa batas, dapat melakukan pertukaran informasi, hiburan dan pendidikan di seluruh dunia sehingga menyebabkan perubahan masyarakat yang sangat pesat, perubahan teknologi, sosial, ekonomi dan budaya.

Dengan perkembangan masyarakat yang begitu pesat serta perkembangan kemajuan teknologi dengan penggunaan internet selain berdampak positif juga dapat berdampak dengan meningkatnya kejahatan yang muncul dengan berbagai macam modus operandi berbasis alat berteknologi yang apabila tidak dibarengi dengan perkembangan pengetahuan di masyarakat tentang hukum maka akan menyebabkan seorang menjadi pelaku tindak pidana atau menjadi korban perbuatan pidana tidak jarang anak dijadikan sebagai sasaran korbannya. Salah satu bentuk tindak pidana yang terjadi di masyarakat adalah tindak pidana eksploitasi seksual pada anak melalui internet sehingga perkembangan aturan hukum pun dituntut untuk dapat mengatasi perkembangan persoalan ini.

${ }^{1}$ Ahmad M Ramli, Cyberlaw Dan HAKI Dalam Sistem Hukum Indonesia (Refika Aditama 2004).[4]. 
Persoalan eksploitasi seksual terhadap anak hingga dimasukkan dalam kategori kejahatan kemanusiaan yang harus dicegah dan dihapuskan. Eksploitasi seksual terhadap anak ini selain merupakan perbuatan melanggar hukum, melanggar Konvensi Hak Anak (KHA), juga bertentangan dengan norma agama dan budaya masyarakat beradab. ${ }^{2}$ Tidak ada agama di muka bumi ini yang membolehkan eksploitasi seksual, terlebih dilakukan terhadap anak. Demikian juga tidak ada budaya di tengah masyarakat yang mengizinkan hal tersebut terjadi, sehingga tindakan eksploitasi seksual terhadap anak yang masih terus terjadi merupakan pelanggaran hukum, norma dan susila sekaligus.

Eksploitasi seksual terhadap anak meningkat karena permintaan pasar seks global yang semakin besar, ${ }^{3}$ mengakibatkan munculnya sindikasi dari ruang-ruang tersebut untuk menarik keuntungan ekonomi dengan berbagai modus baik berupa pelacuran anak, pornografi anak, perdagangan anak, pariwisata anak dan perkawinan anak. Kenyataan di masyarakat dari generasi ke generasi, eksploitasi seksual anak terjadi dan sebagai fakta menyimpangan yang menahun. Ini merupakan perbuatan yang dilarang undang-undang di mana pun di muka bumi karena melanggar hakhak anak dan dapat menimbulkan dampak buruk bagi perkembangan anak sehingga perlindungan anak harus diperhatikan dan usaha perlindungan anak dapat merupakan suatu tindakan hukum yang mempunyai akibat hukum, sehingga menghindarkan anak dari tindakan orang tua yang sewenangwenang. ${ }^{4}$

Bentuk eksploitasi seksual anak dibagi menjadi tiga yakni pelacuran anak, pornografi dan perdagangan anak dengan tujuan seksual termasuk dalam jenis eksploitasi seksual yang komersial. ${ }^{5}$ Yang dimaksud anak dalam pengertian ini adalah anak berdasarkan Pasal 1 ayat (1) UU Republik Indonesia Nomor 23 Tahun

${ }^{2}$ Nurman Syarif, 'Kekerasan Fisik Dan Seksual (Analisis Terhadap Pasal 5 A Dan C No. 23 UU PKDRT Tahun 2004 Ditinjau Dari Perspektif Hukum Islam)’ (2012) 10 Al-'Adalah.[423-434].

${ }^{3}$ FNH, 'Perjelas Kompensasi Bagi Anak Korban Eksploitasi Seks : Anak Yang Menjadi Korban Eksploitasi Seksual Terus Bertambah' (Hukum Online.com) $<$ https://www.hukumonline.com/ berita/baca/lt52b1218c35bc1/perjelas-kompensasi-bagi-anak-korban-eksploitasi-seks $>$ accessed 14 January 2019.

${ }^{4}$ Irma Setyowati Soemitro, Aspek Hukum Perlindungan Anak (Bumi Aksara 1990).[3].

${ }^{5}$ ECPAT, Eksploitasi Seksual Komersial Anak (Restu Printing 2002).[4]. 
2002 tentang Perlindungan Anak adalah : "Anak adalah seseorang yang belum berusia 18 (delapan belas) Tahun, termasuk anak yang masih di dalam kandungan". ${ }^{6}$

Dampak negatif dari perkembangan kemajuan Teknologi Informatika (TI) yaitu terjadinya kejahatan pornografi anak melalui media cetak dan media internet yang nyatanya telah membawa anak pada masa depan yang suram, yang dapat mengakibatkan rusaknya generasi penerus bangsa, sedangkan perangkat hukum perlindungan yang ada terhadap kasus eksploitasi seksual terhadap anak melalui fasilitas teknologi khususnya masih kurang relevan untuk digunakan sebagai dasar hukum yang tepat dibandingkan dengan akibat yang terjadi baik terhadap kerusakan mental dan psikis yang dialami korban dan keluarganya, maupun pengrusakan dan penghancuran generasi bangsa.

Tidak dapat dinafikan fakta pesatnya perkembangan teknologi turut serta meningkatkan angka eksploitasi seksual pada anak (ESA). Data yang dirilis perJanuari hingga Juni 2016, Indonesia menduduki posisi pertama ESA di Asia, dengan mengantongi 161 ribu kasus. Bahkan di Tahun 2017 dan 2018 lalu terungkap beberapa kasus besar ESA berjaringan internasional dengan daerah operasional di berbagai daerah di tanah air. ${ }^{7}$ Fakta ini merupakan fenomena gunung es yang jika digali lagi akan ditemukan kenyataan yang sesungguhnya bahwa masalah ESA ini sudah genting dan perlu penegakan hukum untuk mengatasi. Ibarat fenomena gunung es, kasus ini makin didalami makin banyak ditemukan faktafakta baru sehingga juga perlu diatasi dengan pola penangan tersendiri demikian juga perangkat hukumnya harus lebih dapat mengatasi jerat hukumnya. ${ }^{8}$

Menurut data International Labour organization (ILO) memperkirakan 30 persen dari 240 ribu pekerja seks komersial di Indonesia pada tahun 2017 adalah anak di bawah 18 tahun. Sebagian besar kasus perdagangan orang adalah untuk memperkerjakan anak dalam kegiatan hiburan hingga prostitusi atau eksploitasi

\footnotetext{
${ }^{6}$ Undang-Undang Perlindungan Anak Nomor 35 Tahun 2014 tentang Perubahan Undang-Undang Nomor 23 Tahun 2002 tentang Perlindungan Anak, Pasal 1 Angka (1).

${ }^{7}$ Guntoro dan Paramita Utamadi Utamadi, Pelecehan Seksual (2001).[45-46].

${ }^{8}$ Shofiyul Fuad Hakiki, 'Eksploitasi Jasa Anak Menurut Undang-Undang Nomor 23 Tahun 2002 Dan Hukum Pidana Islam', (2017) 2 Al-Jinayah: Jurnal Hukum Pidana Islam.[ 275-302.]
} 
seksual anak. Motif dari para pelaku pada dasarnya sama, yaitu untuk mendapatkan keuntungan yang sangat besar dengan mempekerjakan perempuan, dimana perempuannya yang semakin muda semakin menjanjikan keuntungan yang berlipat sehingga memicu dan memacu para petualang, pencari keuntungan dan penumpang gelap terus bergerak di tindak pidana yang menjadi bisnis haram ini.

Tindak kejahatan eksploitasi seksual terhadap anak semakin marak terjadi melalui media internet dengan modus yang bermacam-macam. Terkait dengan aturan hukum terhadap tindak pidana eksploitasi seksual anak melalui media internet di Indonesia terkandung dalam Pasal 27 ayat (1) UU Republik Indonesia Nomor 19 tahun 2016 tentang perubahan atas UU Republik Indonesia Nomor 11 Tahun 2008 Tentang Informasi dan Transaksi Elektronik yang berbunyi :

"setiap orang dengan sengaja dan tanpa hak mendistribusikan dan/atau mentransmisikan dan/atau membuat dapat diaksesnya Informasi Elektronik dan/atau dokumen Elektronik yang memiliki muatan yang melanggar kesusilaan". 9

Namun juga ada beberapa aturan perundang-undangan yang mengatur tentang pertanggungjawaban hukum tindak pidana eksploitasi seksual komersial pada anak diantaranya UU Republik Indonesia Nomor 21 Tahun 2007 tentang Pemberantasan Tindak Pidana Perdagangan Orang, UU Republik Indonesia Nomor 44 tahun 2008 tentang Pornografi, dan UU Republik Indonesia Nomor 17 Tahun 2016 tentang Penetapan Peraturan Pemerintah Pengganti UU Nomor 1 Tahun 2016 menjadi undang-undang tentang Perubahan Kedua atas UU Republik Indonesia Nomor 23 Tahun 2002 tentang Perlindungan Anak Jo UU Republik Indonesia Nomor 35 Tahun 2014 tentang Perubahan atas UU Republik Indonesia Nomor 23 Tahun 2002 tentang Perlindungan Anak.

Berdasarkan analisis penulis, dalam hal melakukan tindak pidana eksploitasi seksual anak, para pelaku menggunakan media yang sangat mudah digunakan para pelaku yaitu menggunakan media internet atau online. Maraknya penggunaan media internet ini diakui berkembang lebih cepat, bahkan tidak hanya

\footnotetext{
${ }^{9}$ Pasal 27 ayat (1) UU Republik Indonesia Nomor 19 tahun 2016 tentang perubahan atas UU Republik Indonesia Nomor 11 Tahun 2008 Tentang Informasi dan Transaksi Elektronik.
} 
aparat penegak hukumnya saja yang menjadi kesulitan mengantisipasi, perangkat aturan hukumnya pun dapat dikatakan ketinggalan untuk mengantisipasi dan menjerat para pelaku.

Kesulitan penegak hukum itu karena modus yang digunakan saat ini makin sumir untuk diteruskan ke proses lebih lanjut dalam penegakan hukum karena para pelaku melakukan perbuatannya dengan cara mencari pelanggan yang akan menggunakan jasa seksual anak dengan menyuruh korban untuk seakanakan bertransaksi sendiri, mencari sendiri sehingga para pihak yang terlibat pun tidak dapat dijerat secara langsung. Mereka umumnya bersembunyi di balik layar sehingga ketika pihak berwajib mengusut sering kehilangan jejaknya. Dalam penyelidikan dan penyidikan kasus dengan modus baru sering kurang jelas antara korban dan pelaku. Hal ini menunjukan bahwa sangat sulit jeratan bagi korban apabila sudah masuk dalam jurang perdagangan orang untuk tujuan dieksploitasi secara seksual.

Di tengah perkembangan pesat bentuk-bentuk baru eksploitasi seksual anak, perangkat aturan hukum di Indonesia belum mampu mengakomodasi permasalahan yang terjadi. Praktik eksploitasi seksual anak terus berlangsung, seakan anak-anak “dihal alkan” untuk dieksploitasi oleh para penikmat seks anak meski jerat hukum dan aturan perlindungan juga sudah dibuat dengan sangat ketat. Tidak cukup dengan jerat hukum bagi pelaku, pencegahan dan perlindungan bagi korban pun dibuat, misalnya untuk mencegah terjadinya eksploitasi seksual terhadap anak, selain undang-undang juga dikeluarkan Perpres Nomor 25 Tahun 2012 tentang Gugus Tugas Pencegahan dan Penanganan Pornografi. Ini merupakan salah satu upaya agar eksploitasi seksual terhadap anak tidak mewabah. Banyak strategi yang dituangkan di dalamnya tapi eksekusinya masih belum maksimal. Harusnya, aksi dalam menyikapi isu ini tidak hanya dilakukan pada tataran rancangan aksi pencegahan nasional melainkan dalam bentuk nyata bekerjasama melibatkan masyarakat secara aktif. Juga melibatkan para penyedia jasa layanan internet.

Berbicara mengenai media komunikasi teknologi internet saat ini dijadikan sarana yang efektif untuk perbuatan melawan hukum. Oleh karenanya, 
perbuatan yang dilakukan secara elektronik juga harus diatur dalam undangundang agar tidak lolos dari jerat hukum. Hal tersebut yang membuat negaranegara di dunia memberikan perhatian khusus terhadap pentingnya regulasi di bidang teknologi komunikasi yang dikenal dengan cyberlaw. ${ }^{10}$ Saat ini di Indonesia keberadaan regulasi yang secara khusus mengatur kegiatan di dunia maya yang dapat dijadikan dasar hukum untuk semua bentuk perbuatan hukum secara komprehensif sudah ada yaitu dalam UU Republik Indonesia Nomor 19 tahun 2016 tentang perubahan atas UU Republik Indonesia Nomor 11 Tahun 2008 Tentang Informasi dan Transaksi Elektronik, namun undang-undang Informasi dan Transaksi Elektronik tidak mengatur secara khusus mengenai bentuk-bentuk kejahatan di dunia maya (cybercrime) termasuk bentuk kejahatan eksploitasi seksual terhadap anak melalui internet karena berbicara mengenai tindak pidana eksploitasi seksual pada anak melalui internet tidak terlepas dari pertanggungjawaban hukum untuk mempertanggungjawabkan perbuatan pidana tindak pidana.

Berdasarkan uraian pada latar belakang masalah tersebut diatas, terdapat permasalahan dalam penelitian ini yaitu mengenai pertanggungjawaban hukum pelaku eksploitasi seksual pada anak melalui internet. Penelitian ini menggunakan tipe penelitian yuridis normatif dengan pendekatan undang-undang dan pendekatan konseptual. Pendekatan undang-undang dilakukan dengan menelaah semua undangundang dan regulasi yang bersangkut paut dengan isu hukum yang sedang di tangani. ${ }^{11}$ Pendekatan konseptual beranjak dari pandangan-pandangan dan doktrindoktrin yang berkembang di dalam ilmu hukum. ${ }^{12}$ Dengan mempelajari pandanganpandangan dan doktrin-doktrin di dalam ilmu hukum, peneliti akan menemukan ide-ide yang melahirkan pengertian-pengertian hukum, konsep-konsep hukum, dan asas-asas hukum yang relevan dengan isu yang dihadapi.

\footnotetext{
${ }^{10}$ Ramli (n 1). Op.Cit.[4].

11 Peter Mahmud Marzuki, Penelitian Hukum, (Kencana Prenada Media Group 2005).[17].

12 ibid.[93].
} 


\section{Pertanggungjawaban hukum pelaku tindak pidana eksploitasi seksual pada anak melalui internet}

Dipidananya seseorang tidak hanya cukup dengan membuktikan bahwa orang tersebut telah melakukan perbuatan yang bertentangan dengan hukum atau yang bersifat melawan hukum. Walaupun perbuatannya memenuhi rumusan delik dalam undang-undang dan tidak dibenarkan, namun hal tersebut belum dapat memenuhi syarat untuk penjatuhan pidana. Untuk dapat dipertanggungjawabkannya orang tersebutmasih perluadanya syarat, bahwa orang yang melakukan perbuatan itu mempunyai kesalahan atau bersalah (subjective guilt). Dengan kata lain orang tersebut harus dapat dipertanggungjawabkan atas perbuatannya atau jika dilihat dari sudut perbuatannya, perbuatannya harus dapat dipertanggungjawabkan kepada orang tersebut.

Menurut hukum tidak ada kesalahan tanpa melawan hukum, teori ini kemudian diformulasikan sebagai "tiada pidana tanpa kesalahan atau geen starf zonder schuld atau yang dalam bahasa latin actus reus mens rea". ${ }^{13}$ Asas ini merupakan dasar dari pertanggungjawaban pidana dan tidak ditemukan dalam undang-undang.Berbicara mengenai pertanggungjawaban pidana, berarti berbicara mengenai orang yang melakukan perbuatan pidana. Hukum pidana memisahkan antara karakteristik perbuatan yang dijadikan tindak pidana dan karakteristik orang yang melakukan.Orang yang melakukan perbuatan pidana belum tentu dijatuhi pidana, tergantung apakah orang tersebut dapat dimintakan pertanggungjawaban pidana ataukah tidak. Sebaliknya, seseorang yang dijatuhi pidana, sudah pasti telah melakukan perbuatan pidana dan dapat dipertanggungjawaban. Elemen penting dari pertanggungjawaban pidana adalah kesalahan.

Elemen pertama dari kesalahan adalah kemampuan bertanggungjawab atau toerekeningsvatbaarheid. ${ }^{14}$ Dalam memberikan definisi pertanggungjawaban, seperti yang telah diutarakan diatas, sebenarnya van Hamel telah memberi ukuran

\footnotetext{
${ }^{13}$ Moeljatno, Asas-Asas Hukum Pidana (Rineka Cipta 1983).[37]. 2014).[128].

${ }^{14}$ Eddy O.S. Hiariej, Prinsip-Prinsip Hukum Pidana. Yogyakarta (Cahaya Atma Pustaka
} 
mengenai kemampuan bertanggung jawab yang meliputi tiga hal yaitu: ${ }^{15}$

1. Mampu memahami secara sungguh-sungguh akibat dari perbuatannya;

2. Mampu untuk menginsyafi bahwa perbuatan itu bertentangan dengan ketertiban masyarakat;

3. Mampu untuk menentukan kehendak berbuat.

Ketiga kemampuan tersebut bersifat kumulatif. Artinya, salah satu saja kemampuan bertanggungjawab tidak terpenuhi, maka seseorang dianggap tidak dapat dipertanggungjawabkan. Kemampuan bertanggungjawab dalam KUHP dirumuskan secara negatif, dan tidak dirumuskan secara positif.

Pasal 44 KUHP menyatakan :

Tidak mampu bertanggung jawab :

(1)Barang siapa melakukan perbuatan yang tidak dapat dipertanggungjawabkan padanya, disebabkan karena jiwanya cacat dalam tubuhnya atau terganggu karena penyakit, tidak dipidana.

(2)Jika ternyata bahwa perbuatan tidak dapat dipertanggungjawabkan padanya disebabkan karena jiwanya cacat dalam tubuhnya atau terganggu karena penyakit, maka hakim dapat memerintahkan supaya orang itu dimasukkan ke dalam rumah sakit jiwa, paling lama satu tahun sebagai waktu percobaan.

(3)Ketentuan tersebut dalam ayat (2) hanya berlaku bagi Mahkamah Agung, Pengadilan Tinggi dan Pengadilan Negeri. ${ }^{16}$

Dasar untuk memidana baik terhadap pelanggaran maupun kejahatan (tindak pidana) terdapat didalam pasal 1 ayat (1) KUHP yang berbunyi: "tiada suatu perbuatan dapat dipidana kecuali atas kekuatan anturan pidana dalam perundang-undangan yang telah ada, sebelum perbuatan dilakukan." ${ }^{17}$

${ }^{15}$ Andi Hamzah, Pengantar Hukum Acara Pidana Indonesia (Ghalia Indonesia 1985).[108].

16 Pasal 44 Undang-Undang Nomor 1 Tahun 1946 tentang Peraturan Hukum Pidana Jo Undang -undang Nomor 73 Tahun 1958 tentang Menyatakan Berlakunya Undang-undang Nomor 1 Tahun 1946 Republik Indonesia tentang Peraturan Hukum Pidana Untuk Seluruh Wilayah Republik Indonesia dan Mengubah Undang-undang Hukum Pidana (Lembaran Negara Nomor 127 Tahun 1958, Tambahan lembaran Negara Nomor 1660 Tahun 1958);

17 Pasal 1 ayat (1) Undang-Undang Nomor 1 Tahun 1946 tentang Peraturan Hukum Pidana Jo Undang -undang Nomor 73 Tahun 1958 tentang Menyatakan Berlakunya Undang-undang Nomor 1 Tahun 1946 Republik Indonesia tentang Peraturan Hukum Pidana Untuk Seluruh Wilayah Republik Indonesia dan Mengubah Undang-undang Hukum Pidana (Lembaran Negara Nomor 127 Tahun 1958, Tambahan lembaran Negara Nomor 1660 Tahun 1958); 
Pertanggungjawaban pidana mengarah pada pemidanaan pelaku, jika melakukan tindak pidana dan telah memenuhi unsur-unsurnya dalam Undangundang. Dilihat dari sudut terjadinya, maka seseorang akan dipertanggungjawabkan pidana apabila tindakan tersebut melawan hukum.

Pelaku dalam tindak pidana eksploitasi seksual terhadap anak melalui internet tidak memiliki profil secara khusus melainkan bisa siapapun, baik laki-laki atau perempuan, orang terdekat ataupun orang asing, dari berbagai tingkatan usia, struktur sosial, ekonomi, berbagai suku, negara dan agama. ${ }^{18}$

Untuk mengenali perilaku dari pelaku kejahatan seksual terhadap anak melalui internet yaitu pelaku menggunakan teknologi untuk berlindung dari kejahatannya dengan menggunakan interaksi internet secara online (media sosial, Apps, dan fasilitas chat di game online), Aplikasi/program yang memberikan fasilitas streaming/siaran langsung), menggunakan TOR/PROXI/VPN, menggunakan transaksi uang virtual (uang elektrik, bit coin, transfer pulsa), menggunakan enkripsi, steganography, penyimpanan cloud, pelaku selalu membangun komunikasi intensif dengan korban, kemudian secara bertahap melakukan komunikasi lebih tertutup dan meningkatkan pembicaraan kearah seksualitas, pelaku memainkan psikologis anak, membangun hubungan emosional dengan anak, melakukan bujuk rayu, memberi hadiah, atau dengan ancaman, pelaku dapat berjejaring dengan sindikat internasional atau pelaku melakukan kejahatan sendiri.

Pelaku kejahatan eksploitasi seksual terhadapanakmelaluiinternet dikategorikan sebagai pelaku preferensial yaitu pelaku kejahatan dengan kecenderungan orientasi seksual yang hanya menargetkan anak untuk dieksploitasi secara seksual sedangkan pelaku situasional yaitu pelaku kejahatan tidak mengkhususkan anak sebagai korban eksploitasi seksual, namun karena situasi yang tersedia pelaku memanfaatkan situasi tersebut untuk kepuasan seksualnya terhadap anak. ${ }^{19}$

18 Tim ECPAT, 'Modul Eksploitasi Seksual Anak Di Ranah Online Untuk Anak' (Tim ECPAT, 2018) <https:/www.slideshare.net/ecpatindonesia/modul-eksploitasi-seksual-anak-online-ecpat-anak> accessed 12 February 2019.

19 ibid. 
Perbedaan pelaku preferensial dan pelaku situasional yaitu:

\section{- Pelaku Preferensial}

- Memiliki orientasi seksual khusus dengan anak.

- Memiliki hubungan emosional dalam melibatkan anak.

- Sangat aktif mencari target baru.

- Sangat manipulatif dan memiliki kemampuan mempengaruhi anak sangat baik.

- Jumlahnya sangat sedikit tetapi membawa dampak kerusakan yang sangat besar.

\section{- Pelaku Situasional}

- Tidak memiliki orientasi seksual khusus dengan anak.

- Mengambil keuntungan dan memanfaatkan situasi yang ada.

- Kadangkala menjadi pelaku kejahatan utama, namun umumnya berperan sebagai perantara dalam struktur kejahatan menjadi orang-orang yang mempertahankan situsi ini terjadi (seperti germo/mucikari, fasilitator, pihak yang mempromosikan/menawarkan, memverifikasi).

- Terlibat secara pasif dan hanya mau terlibat bila keadaan menguntungkan.

- Jumlahnya sangat besar, keberadaan pelaku ini yang menopang permintaan akan eksploitasi seksual anak melalui internet tetap terjaga.

Pelaku prefensial maupun pelaku situasional yang bertindak sebagai mucikari atau germo merupakan orang yang berperan sebagai pengasuh, perantara atau pemilik pekerja seks komersial anak dikatakan melakukan aktivitasnya dengan akal yang sehat dan dapat membedakan mana yang diperbolehkan dan mana yang tidak. Mengenai kehendak yang ada pada pelaku (mucikari/germo) dalam tindak pidana eksploitasi seksual terhadap anak melalui internet ini dapat dilihat dari alasan ekonomi yang secara umum merupakan alasan mereka mau terjun untuk menjalankan bisnis prostitusi.

Dalam kerangka pertanggungjawaban di internet paling tidak ada 7 (tujuh) pihak yang bertanggungjawab sesuai dengan perannya masing-masing saat yang bersangkutan berinteraksi dengan menggunakan internet, diantaranya yaitu pengguna internet, operator telekomunikasi, Internet Service Provider (ISP), server, packager, prosedur, author20 namun hal tersebut masih sulit untuk

\footnotetext{
20 Syarif (n 2).L Heru Sujamawardi, 'Analisis Yuridis Pasal 27 Ayat (1) Undang-Undang Nomor 19 Tahun 2016 Tentang Perubahan Atas Undang-Undang Nomor 11 Tahun 2008 Tentang Informasi Dan Transaksi Elektronik’ (2018) 9.
} 
dikenakan karena membutuhkan perangkat hukum yang canggih dan didukung dengan sarana yang canggih serta aparat hukum yang memiliki keahlian di bidang teknologi informatika.

Dalam hal penegakan hukum tindak pidana eksploitasi seksual anak melalui internet sejauh ini memang belum terbahas secara maksimal dan merupakan konsep yang belum banyak dibahas khususnya dalam lingkup hukum pidana. Yang dimaksud Eksploitasi Seksual Anak menurut UU Republik Indonesia Nomor 35 Tahun 2014 tentang Perubahan atas UU Republik Indonesia Nomor 23 Tahun 2002 tentang Perlindungan Anak adalah keterlibatan anak dalam kegiatan seksual yang dipahaminya. Dalam hal ini, eksploitasi seksual berarti suatu perlakuan yang tidak senonoh dari orang lain, kegiatan yang menjurus pada suatu yang dikenal dengan kata pornografi, perkataan porno, menelanjangi anak, membuat anak malu, dan menggunakan anak untuk produk pornografi dan melibatkan dalam bisnis prostitusi.

Eksploitasi seksual anak yang didefinisikan sebagai kegiatan yang melibatkan anak laki-laki maupun perempuan, demi uang, kesenangan satu pihak, keuntungan atau pertimbangan lain karena paksaan atau pengaruh orang dewasa, oknum, sindikat atau kelompok, terkait dengan hubungan seksual atau perilaku yang menimbulkan birahi.

Berdasarkan penelitian ECPAT (End Child Prostitution, Child Pornography and Trafficking of Children for Sexual Purposes) bentuk-bentuk dari Eksploitasi Seksual Anak yang terjadi pada kondisi online melalui internet, diantaranya:

\section{- Grooming online untuk tujuan seksual}

Adalah sebuah proses untuk menjalin atau membangun sebuah hubungan dengan seorang anak melalui penggunaan Internet atau teknologi digital lain dengan maksud untuk memancing, memanipulasi atau menghasut anak agar anak bersedia melakukan kegiatan seksual.

\section{- $\quad$ Sexting}

Adalah proses seorang anak secara intens mengirimkan pesan seksual secara eksplisit atau gambar yang menunjukkan sisi seksualitas dari dirinya. Gambar atau video yang dikirimkan ini bisa berupa tampilan (semi- telanjang), erotis, dan atau 
aktivitas seksual dan biasanya dibagikan kepada pacar atau teman dekat.

\section{- $\quad$ Pemerasan Seksual (Sextortion)}

Disebut juga pemerasan terhadap seorang anak dengan bantuan gambar agar orang tersebut (yang dibuat sendiri) untuk mendapatkan imbalan seks, uang atau keuntungan lain dari orang tersebut dibawah ancaman penyebaran materi tersebut tanpa persetujuan dari orang yang digambarkan (misalnya mengirimkan gambar di media sosial).

\section{- $\quad$ Siaran langsung perilaku seksual pada anak}

Adalah terjadi ketika seorang anak dipaksa untuk tampil di depan kamera atau webcam untuk melakukan aktivitas seksual atau menjadi subjek dari eksploitasi seksual. Aktivitas ini kemudian dibuat siaran langsungnya melalui internet kepada para pelanggan yang berbayar (pelaku/predator seks) yang menonton dan atau meminta bagaimana tindakan eksploitasi tersebut dilakukan melalui webcam.

\section{- $\quad$ Child Sexual Abuse Material (CSAM).}

Dalam terjemahan bahasa Indonesia CSAM berarti materi yang mengandung muatan eksploitasi seksual terhadap anak. Adapun definisi CSAM adalah setiap perwujudan melalui sarana apapun, seorang anak terlibat dalam situasi nyata atau disimulasikan secara eksplisit melakukan aktifitas seksual atau perwujudan lain dari organ seks anak, utamanya untuk tujuan seksual.

Berdasarkan uraian diatas dapat disimpulkan bahwa bentuk-bentuk Eksploitasi Seksual Anak online tersebut termasuk dalam Kualifikasi Kejahatan yang diawali dengan Pornografi. Oleh sebab itu, rumusan pengaturannya menurut hukum yang berlaku di Indonesia yaitu lex specialist. Sebuah penelusuran penulis, belum ada aturan lex specialist tentang eksploitasi seksual anak melelui internet di Indonesia, karena dalam hal perlindungan anak diintegrasikan ke dalam undang-undang perlindungan anak sedangkan media internet diintegrasikan ke dalam undangundang Informasi Transaksi Elektronik dan peraturan perundangan lainnya.

Sementara itu, dalam UU Republik Indonesia Nomor 17 Tahun 2016 tentang Penetapan Peraturan Pemerintah Pengganti UU Nomor 1 Tahun 2016 menjadi undang-undang tentang Perubahan Kedua atas UU Republik Indonesia Nomor 
23 Tahun 2002 tentang Perlindungan Anak Jo UU RI Nomor 35 Tahun 2014 tentang Perubahan atas UU Republik Indonesia Nomor 23 Tahun 2002 tentang Perlindungan Anak juga tidak menempatkan tindak pidana eksploitasi seksual anak melalui internet dalam bab khusus. Upaya memunculkan pasal-pasal tentang tindak pidana eksploitasi seksual anak melalui internet diperjuangkan dalam UU Republik Indonesia Nomor 17 Tahun 2016 tentang Penetapan Peraturan Pemerintah Pengganti Undang-Undang Nomor 1 Tahun 2016 menjadi undang-undang tentang Perubahan Kedua atas UU Republik Indonesia Nomor 23 Tahun 2002 tentang Perlindungan Anak Jo UU RI Nomor 35 Tahun 2014 tentang Perubahan atas UU Republik Indonesia Nomor 23 Tahun 2002 tentang Perlindungan Anak dan beberapa undang-undang lain yang mengatur persoalan ini, seperti UU Republik Indonesia Nomor 44 Tahun 2008 tentang Pornografi yang juga mengatur tentang tindak pidana eksploitasi seksual anak dalam kategori pornografi anak. Namun, belum ada pasal-pasal yang secara khusus mengatur tentang eksploitasi seksual pada anak melalui internet.

Untuk menentukan sebuah tindak pidana seperti tindak pidana eksploitasi seksual anak melalui internet lazimnya dikembalikan pada doktrin dan instrumen-instrumen hukum yang lebih dulu berlaku di dunia internasional. Dalam hal ini, seperti Deklarasi Stockholm, atau Protocol Optional tentang Sale of Children, Child Prostitution and Child Pornography yang kemudian diratifikasi oleh Indonesia melalui Undang-Undang Republik Indonesia Nomor 10 Tahun 2012 tentang konvensi hak Anak (KHA). ${ }^{21}$ Lembaga internasional lain yang hingga penelitian ini disusun masih menjadi rujukan penting dalam kasus atau masalah eksploitasi anak adalah End Child Prostution and Trafficking (ECPAT Internasional). ${ }^{22}$ Oleh karena itu dalam pertimbangan pemikiran dasar hukumnya, penulis menggunakan isi Convention on Cybercrime tahun 2001,

${ }^{21}$ United Nations Human Rights, 'Optional Protocol To The Convention On The Rights Of The Child On The Sale Of Children, Child Prostitution And Child Pornography’ (United Nations Human Rights) <https://www.ohchr.org/en/professionalinterest/pages/opsccrc.aspx>.

22 ECPAT, 'Memerangi Pariwisata Sex Anak' (2008). 
khususnya yang terkandung pada Pasal 9 dan penulis lebih menfokuskan bentuk kejahatan eksploitasi seksual terhadap anak yang dilakukan melalui media internet pada isi Convention on Cybercrime tahun 2001, khususnya yang terkandung pada Pasal 9 yaitu pada point 3 (producing child pornography for the purpose of its distribution through a computer system), 4 (offering or making available child pornography through a computer system), 5 (distributing or transmitting child pornography through a computer system), 6 (procuring child pornography through a computer system for oneself or for another person) dan 7 (possessing child pornography in a computer system or on a computer-data storage medium) karena pada point tersebut mencantumkan medianya yaitu melalui sistem komputer.

Sistem komputer diartikan sebagai sebuah jaringan elektronik yang saling bekerjasama, terdiri dari perangkat lunak (software) dan perangkat keras (hardware) untuk melakukan tugas tertentu. Tugas itu bisa berupa menerima input, menyimpan perintah-perintah, memproses input, dan menyediakan output yang melibatkan komputer di dalamnya.

Hardware merupakan perangkat keras dari sistem komputer yang memiliki wujud fisik yang dapat disentuh yaitu Central Processing Unit (CPU), Input Unit, Output Unit dan Storage Unit.

Sedangkan Software adalah komponen dari komputer yang tidak memiliki wujud atau bentuk fisik. Software memiliki wujud digital yang tersimpan pada memori komputer. Terdapat berbagai macam jenis kategori software pada sistem komputer yaitu system software yang merupakan sistem operasi komputer, Utility Software yang menjaga dan melindungi sistem komputer dan Application Software adalah yang digunakan oleh user untuk menyelesaikan tugas tertentu termasuk didalamnya yaitu internet, web browser, software office, game dan lainnya.

Berdasarkan uraian diatas dapat disimpulkan bahwa internet merupakan bagian dari sistem komputer sehingga dasar pemikiran penulis terhadap kejahatan eksploitasi seksual pada anak melalui internet menggunakan isi Convention on Cybercrime tahun 2001, khususnya yang terkandung pada Pasal 9. 
Indonesia saat ini memang belum memiliki undang-undang yang khusus mengatur masalah eksploitasi seksual komersial anak. Undang-undang hanya memasukan eksploitasi seksual komersial anak secara terpisah di beberapa peraturan pidana lain, seperti dalam UU Republik Indonesia Nomor 44 tahun 2008 tentang Pornografi, UU Republik Indonesia Nomor 17 Tahun 2016 tentang Penetapan Peraturan Pemerintah Pengganti Undang-Undang Nomor 1 Tahun 2016 menjadi undang-undang tentang Perubahan Kedua atas UU Republik Indonesia Nomor 23 Tahun 2002 tentang Perlindungan Anak Jo UU Republik Indonesia Nomor 35 Tahun 2014 tentang Perubahan atas Undang-Undang Republik Indonesia Nomor 23 Tahun 2002 tentang Perlindungan Anak dan lainnya. Dalam UU Republik Indonesia Nomor 44 tahun 2008 tentang Pornografi, pornografi anak hanya menjadi bagian dari tindak pidana intinya yaitu pidana pornografi, begitu juga yang terdapat dalam UU Republik Indonesia Nomor 21 Tahun 2007 tentang Pemberantasan Tindak Pidana Perdagangan Orang, dimana perdagangan anak dengan tujuan eksploitasi seksual hanya masuk menjadi salah satu bagian saja dalam UU Republik Indonesia Nomor 21 Tahun 2007 tentang Pemberantasan Tindak Pidana Perdagangan Orang. Di Indonesia pertanggungjawaban hukum terhadap pelaku tindak pidana eksploitasi seksual pada anak melalui internet diatur dalam peraturan perundang-undangan diantaranya ${ }^{23}$ :

\section{UU Republik Indonesia Nomor. 44 Tahun 2008 tentang Pornografi} Pasal 1

"Pornografi adalah gambar, sketsa, ilustrasi, foto, tulisan, suara, bunyi, gambar bergerak, animasi, kartun, percakapan, gerak tubuh, atau bentuk pesan lainnya melalui berbagai bentuk media komunikasi dan/atau pertunjukan di muka umum, yang memuat kecabulan atau eksploitasi seksual yang melanggar norma kesusilaan dalam masyarakat. ${ }^{24}$,

Pasal 4

(1) "Setiap orang dilarang memproduksi, membuat, memperbanyak, menggandakan, menyebarluaskan, menyiarkan, mengimpor, mengekspor, menawarkan, memperjualbelikan, menyewakan, atau menyediakan pornografi

${ }^{23}$ Febri Dwi Yanto, 'Analisis Yuridis Ketentuan Pertanggungjawaban Pidana Bagi Pelaku Prostitusi Online Di Indonesia' (2017) 1 Legal Spirit.

${ }^{24}$ Undang-Undang Republik Indonesia Nomor. 44 Tahun 2008 tentang Pornografi pasal 1. 
yang secara eksplisit memuat :

a. Persenggamaan, termasuk persenggamaan yang menyimpang;

b. Kekerasan seksual;

c. Masturbasi atau onani;

d. Ketelanjangan atau tampilan yang mengesankan ketelanjangan;

e. Alat kelamin; atau

f. Pornografi anak. ${ }^{25}$

Pasal 11

"Setiap orang dilarang melibatkan anak dalam kegiatan dan/atau sebagai objek sebagaimana yang dimaksud dalam Pasal 4, pasal 5, pasal 6, pasal 8, pasal 9, atau pasal 10"26

Pasal 29

"Setiap orang yang memproduksi, membuat, memperbanyak, menggandakan, menyebarluaskan, menyiarkan, mengimpor, mengekspor, menawarkan, memperjualbelikan,menyewakan, atau menyediakan pornografi sebagaimana dimaksud dalam Pasal 4 ayat (1) dipidana dengan pidana penjara paling singkat 6 (enam) bulan dan paling lama 12 (dua belas) tahun dan/atau pidana denda paling sedikit Rp. 250.000.000,00 (dua ratus lima puluh juta rupiah) dan paling banyak Rp. 6.000.000.000,00 (enam miliar rupiah)." ${ }^{27}$

Pasal 37

"Setiap orang yang melibatkan anak dalam kegiatan dan/atau sebagai objek sebagaimana dimaksud dalam Pasal 11 dipidana dengan pidana yang sama dengan pidana sebagaimana dimaksud dalam Pasal 29, Pasal 30, Pasal 31, Pasal 32, Pasal 34, Pasal 35, dan Pasal 36, ditambah 1/3 (sepertiga) dari maksimum ancaman pidananya." 28

2. UU Republik Indonesia Nomor 17 Tahun 2016 tentang Penetapan

Peraturan Pemerintah Pengganti Undang-Undang Nomor 1 Tahun 2016 menjadi undang-undang tentang Perubahan Kedua atas UU Republik

\footnotetext{
ayat (1).

${ }^{25}$ Undang-Undang Republik Indonesia Nomor. 44 Tahun 2008 tentang Pornografi pasal 4

${ }^{26}$ Undang-Undang Republik Indonesia Nomor. 44 Tahun 2008 tentang Pornografi pasal 11.

${ }^{27}$ Undang-Undang Republik Indonesia Nomor. 44 Tahun 2008 tentang Pornografi pasal 29.

${ }^{28}$ Undang-Undang Republik Indonesia Nomor. 44 Tahun 2008 tentang Pornografi pasal 37.
} 


\section{Indonesia Nomor. 23 Tahun 2002 tentang Perlindungan Anak Jo UU}

Republik Indonesia Nomor. 35 Tahun 2014 tentang Perubahan atas UU

Republik Indonesia Nomor. 23 Tahun 2002 tentang Perlindungan Anak

Hanya terdapat dua pasal yang memuat tentang larangan melakukan eksploitasi seksual dan eksploitasi ekonomi pada anak yaitu dalam pasal 76 I dan pasal 88.

Pasal 76 I

"Setiap Orang dilarang menempatkan, membiarkan, melakukan, menyuruh melakukan, atau turut serta melakukan eksploitasi secara ekonomi dan/ atau seksual terhadap Anak". ${ }^{29}$

Pasal 88

"Setiap Orang yang melanggar ketentuan sebagaimana dimaksud dalam Pasal 76I, dipidana dengan pidana penjara paling lama 10 (sepuluh) tahun dan/atau denda paling banyak Rp200.000.000,00 (dua ratus juta rupiah)." 30

Dalam penjelasan undang-undang, mencantumkan definisi dari “dieksploitasi secara seksual" adalah segala bentuk pemanfaatan organ tubuh seksual atau organ tubuh lain dari Anak untuk mendapatkan keuntungan, termasuk tetapi tidak terbatas pada semua kegiatan pelacuran dan eksploitasi. Namun dalam undang-undang ini tidak mencantumkan penjelasan secara rinci mengenai konsep tindak eksploitasi seksual. terhadap anak melalui internet

\section{UU Republik Indonesia Nomor 21 Tahun 2007 tentang Pemberantasan Tindak Pidana Perdagangan Orang}

Larangan mengenai eksploitasi seksual diatur dalam pasal 1 ayat (8) dan pasal 2

${ }^{29}$ Undang-Undang Republik Indonesia Nomor 17 Tahun 2016 tentang Penetapan Peraturan Pemerintah Pengganti Undang-Undang Nomor 1 Tahun 2016 menjadi undang-undang tentang Perubahan Kedua atas UU Republik Indonesia Nomor. 23 Tahun 2002 tentang Perlindungan Anak Jo UU Republik Indonesia Nomor. 35 Tahun 2014 tentang Perubahan atas UU Republik Indonesia Nomor. 23 Tahun 2002 tentang Perlindungan Anak pasal 76I.

${ }^{30}$ Undang-Undang Republik Indonesia Nomor 17 Tahun 2016 tentang Penetapan Peraturan Pemerintah Pengganti Undang-Undang Nomor 1 Tahun 2016 menjadi undang-undang tentang Perubahan Kedua atas UU Republik Indonesia Nomor. 23 Tahun 2002 tentang Perlindungan Anak Jo UU Republik Indonesia Nomor. 35 Tahun 2014 tentang Perubahan atas UU Republik Indonesia Nomor. 23 Tahun 2002 tentang Perlindungan Anak pasal 88. 
ayat (1) dan ayat (2).

Pasal 1 ayat (8)

"Eksploitasi Seksual adalah segala bentuk pemanfaatan organ tubuh seksual atau organ tubuh lin dari korban untuk mendapatkan keuntungan, termasuk tetapi tidak terbatas pada semua kegiatan pelacuran dan pencabulan.",31

Pasal 2 ayat (1)

"setiap orang yang melakukan perekrutan, pengangkutan, penampungan, pengiriman, pemindahan, atau penerimaan seseorang dengan ancaman kekerasan, penggunaan kekerasan, penculikan, penyekapan, pemalsuan, penipuan, penyalahgunaan kekuasaan atau posisi rentan, penjeratan utang atau memberi bayaran atau manfaat walaupun memperoleh persetujuan dari orang yang memegang kendali atas orang lain, untuk tujuan mengeksploitasi orang tersebut di wilayah negara Republik indonesia, dipidana dengan pidana penjara paling singkat 3 (tiga) tahun dan paling lama 15 (lima belas) tahun dan pidana denda paling sedikit Rp. 120.000.000,- (seratus dua puluh juta rupiah) dan paling banyak Rp. 600.000.000,- (enam ratus juta rupiah)., ${ }^{32}$

Pasal 2 ayat (2)

“jika perbuatan sebagaimana dimaksud pada ayat (1) mengakibatkan orang tereksploitasi, maka pelaku dipidana dengan pidana yang sama sebagaimana dimaksud pada ayat (1)." ${ }^{33}$

Dalam pasal ini yang menjadi objek korban dari perbuatan tersebut bisa seorang dewasa ataupun seseorang yang belum dewasa.

\section{UU Republik Indonesia Nomor. 19 Tahun 2016 tentang Perubahan Atas \\ UU Republik Indonesia Nomor. 11 Tahun 2008 tentang Informasi dan Transaksi Elektronik}

Pasal 27

"Setiap Orang dengan sengaja dan tanpa hak mendistribusikan dan/atau mentransmisikan dan/atau membuat dapat diaksesnya Informasi Elektronik

\footnotetext{
${ }^{31}$ Undang-Undang Republik Indonesia Nomor 21 Tahun 2007 tentang Pemberantasan Tindak Pidana Perdagangan Orang pasal 1 ayat (8).

${ }^{32}$ Undang-Undang Republik Indonesia Nomor 21 Tahun 2007 tentang Pemberantasan Tindak Pidana Perdagangan Orang pasal 2 ayat (1).

${ }^{33}$ Undang-Undang Republik Indonesia Nomor 21 Tahun 2007 tentang Pemberantasan Tindak Pidana Perdagangan Orang pasal 2 ayat (2).
} 
dan/atau Dokumen Elektronik yang memiliki muatan yang melanggar kesusilaan." 34

Pasal 45 ayat (1)

"Setiap Orang yang memenuhi unsur sebagaimana dimaksud dalam Pasal 27 ayat (1), ayat (2), ayat (3), atau ayat (4) dipidana dengan pidana penjara paling lama 6 (enam) tahun dan/atau denda paling banyak Rp1.000.000.000,00 (satu miliar rupiah)." 35

Media yang digunakan adalah berupa informasi elektronik dan/atau dokumen elektronik dan yang menjadi objek korban dari perbuatan tersebut bisa seorang dewasa ataupun seseorang yang belum dewasa. Mengenai muatan yang melanggar kesusilaan dalam tindak pidana eksploitasi seksual pada anak melalui internet yaitu pornografi anak dan prostitusi cyber anak.

Unsur yang termuat dalam undang-undang ini yaitu melanggar kesusilaan. Pelanggaran asusila yang dimaksud dalam pengertian suatu tindakan yang melanggar kesusilaan. Menurut Roeslan Saleh "pengertian kesusilaan hendaknya tidak dibatasi pada pengertian kesusilaan dalam bidang seksual, tetapi juga meliputi hal-hal yang termasuk dalam penguasaan norma-norma bertingkahlaku dalam pergaulan masyarakat". sedangkan menurut Barda Nawawi Arief "delik kesusilaan adalah delik yang berhubungan dengan (masalah) kesusilaan”. Namun pengertian dan batas-batas mengenai kesusilaan itu cukup luas dan berbeda-beda tergantung dari cara pandang dan nilai yang berlaku di masyarakat. Delik kesusilaan diatur dalam bab XIV buku II KUHP dengan judul "kejahatan terhadap kesusilaan” yang dimulai dari pasal 281 KUHP sampai dengan 297 KUHP.

Sekilas dari rumusan pasal 27 ayat (1) UU Republik Indonesia Nomor 19 Tahun 2016 tentang perubahan atas UU Republik Indonesia Nomor. 11 Tahun 2008 tentang Informasi dan Transaksi Elektronik tidak menimbulkan permasalahan, karena unsur-unsurnya sudah terpenuhi namun jika dicermati pada aturan umumnya

\footnotetext{
${ }^{34}$ Undang-Undang Republik Indonesia Nomor. 19 Tahun 2016 tentang Perubahan Atas Undang-Undang Republik Indonesia Nomor. 11 Tahun 2008 tentang Informasi dan Transaksi Elektronik pasal 27.

${ }^{35}$ Undang-Undang Republik Indonesia Nomor. 19 Tahun 2016 tentang Perubahan Atas Undang-Undang Republik Indonesia Nomor. 11 Tahun 2008 tentang Informasi dan Transaksi Elektronik pasal 45 ayat (1).
} 
tidak memuat penjelasan mengenai maksud dari muatan yang melanggar kesusilaan sehingga dapat menimbulkan multi tafsir.

Terkait pembahasan dalam penelitian ini, sanksi hukum yang diterima pelaku kejahatan eksploitasi seksual terhadap anak melalui internet berdasarkan pasalpasal yang tersebar di beberapa undang-undang ternyata tidak tunggal alias sangat beragam. Hal itu tergantung jenis perbuatan dan tingkat keterlibatannya.

Dalam hal ini juga dikenal ketentuan bahwa seorang anak yang menjadi pelaku eksploitasi seksual atau kekerasan atau ancaman kekerasan seksual dapat diancam dengan pidana penjara paling lama $1 / 2$ (setengah) dari maksimum ancaman pidana penjara bagi orang dewasa. ${ }^{36}$

Bahkan jika kekerasan atau ancaman kekerasan seksual tersebut dilakukan oleh orang tua, wali, pengasuh anak, pendidik atau tenaga kependidikan maka pidananya ditambah $1 / 3$ (sepertiga) dari maksimum ancaman pidana penjara.

Sementara itu, terkait dengan eksploitasi seksual anak melalui internet juga disebutkan sebagai pelanggaran terhadap pasal 27 ayat (1) UU Republik Indonesia Nomor 19 Tahun 2016 tentang perubahan atas UU Republik Indonesia Nomor. 11 Tahun 2008 tentang Informasi dan Transaksi Elektronik dipidana dengan pidana penjara paling lama enam tahun dan/atau denda paling banyak Rp. 1 milyar. ${ }^{37}$ Dalam pasal 53 UU Republik Indonesia Nomor 19 Tahun 2016 tentang perubahan atas UU Republik Indonesia Nomor. 11 Tahun 2008 tentang Informasi dan Transaksi Elektronik, dinyatakan bahwa seluruh peraturan perundang-undangan yang telah ada sebelumnya dinyatakan tetap berlaku, selama tidak bertentangan dengan UU Republik Indonesia Nomor 19 Tahun 2016 tentang perubahan atas UU Republik Indonesia Nomor. 11 Tahun 2008 tentang Informasi dan Transaksi Elektronik tersebut.

Dalam peraturan perundang-undangan yang secara tegas mengatur tentang pornografi yang di dalamnya termasuk eksploitasi seksual terhadap anak yang

\footnotetext{
${ }^{36}$ Undang-Undang Republik Indonesia Nomor 11 Tahun 2012 tentang Sistem Peradilan Pidana Anak (Lembaran Negara Republik Indonesia Tahun 2012 Nomor 153, Tambahan Lembaran Negara Republik Indonesia Nomor 165);

${ }^{37}$ Pasal 45 ayat 1 Undang-Undang Republik Indonesia Nomor 19 Tahun 2016 tentang perubahan atas Undang-Undang RI Nomor. 11 Tahun 2008 tentang Informasi dan Transaksi Elektronik.
} 
belakangan biasanya dimulai dari tindak asusila di internet adalah UU Republik Indonesia Nomor. 44 Tahun 2008 tentang Pornografi. Larangan penyebarluasan muatan pornografi, termasuk melalui di internet, yang biasanya digunakan sebagai awal terjadinya eksploitasi seksual terhadap anak diatur dalam pasal 4 ayat (1) UU Republik Indonesia Nomor. 44 Tahun 2008 tentang Pornografi.

Pasal 44 UU Republik Indonesia Nomor. 44 Tahun 2008 tentang Pornografi menyatakan bahwa pada saat Undang-Undang ini mulai berlaku, semua peraturan perundang-undangan yang mengatur atau berkaitan dengan tindak pidana pornografi dinyatakan tetap berlaku sepanjang tidak bertentangan dengan undang-undang ini.

Berdasarkan uraian diatas maka pertanggungjawaban pidana dapat dimintakan pertanggungjawabannya apabila memenuhi seluruh unsur yaitu unsur subyektif dan unsur obyektif juga terpenuhinya syarat formil dan syarat materiil. Apabila salah satu unsur ataupun syarat tersebut tidak terpenuhi maka pelaku tidak dapat dimintai pertanggungjawabannya.

Berdasarkan Pasal 4 Undang-Undang RI Nomor. 44 Tahun 2008 tentang Pornografi, pelaku pornografi dengan tujuan eksploitasi seksual anak tidak memenuhi semua unsur eksploitasi seksual anak melalui internet karena hanya memenuhi sebagian unsur saja yakni unsur dengan sengaja secara melawan hukum memproduksi, membuat, memperbanyak, menggandakan, menyebarluaskan, menyiarkan, mengimpor, mengekspor, menawarkan, memperjualbelikan, menyewakan, atau menyediakan pornografi yang secara eksplisit memuat Pornografi anak. Sedangkan unsur melalui internet tidak nyata nyata secara implisit dimuat dalam pasal tersebut. Agar pelaku eksploitassi seksual anak melalui internet tidak lepas dari jerat hukum maka pelakunya dapat dimintakan pertanggungjawaban dengan melakukan pendekatan perundang-undangan yang dalam hal ini melakukan pendekatan dengan perundangan pornografi.

Berdasarkan uraian tersebut media komunikasi bukanlah yang dimaksud dengan media Internet dalam sistem komputer karena belum ada pasal-pasal yang mengatur secara khusus mengenai bentuk-bentuk kejahatan eksploitasi seksual terhadap anak melalui internet. 
Pertanggungjawaban pidana pelaku tindak pidana eksploitasi seksual pada anak melalui internet tidak diatur secara rinci dalam Undang-Undang Nomor 19 tahun 2016 tentang perubahan atas Undang-undang Nomor 11 Tahun 2008 Tentang Informasi dan Transaksi Elektronik yang saat ini dijadikan payung hukum untuk segala bentuk kejahatan di media internet yaitu tidak diatur bentuk-bentuk kejahatan eksploitasi seksual khusus terhadap anak melalui internet. Agar pelaku eksploitasi seksual anak melalui internet tidak lepas dari jerat hukum maka pelakunya dapat dimintakan pertanggungjawaban dengan melakukan pendekatan perundang-undangan yang dalam hal ini melakukan pendekatan dengan perundangan Informasi Transaksi Elektronik, tanpa harus membuktikan unsur anak didalamnya.

\section{Kesimpulan}

Perbuatan eksploitasi seksual pada anak melalui internet merupakan kejahatan karena bertentangan dengan keadilan yang terkait dengan hak-hak anak, perbuatan tersebut belum memenuhi semua unsur-unsur dari tindak pidana yang ada sehingga tidak dapat dimintakan pertanggungjawaban pidananya karena tidak terpenuhinya semua unsur perbuatan pidana yang diatur dalam perundang-undangan yang ada di Indonesia. Agar pelaku eksploitasi seksual anak melalui internet tidak lolos dari jerat hukum, pelaku tersebut dapat dimintakan pertanggungjawaban pidananya dengan menerapkan pendekatan unsur perbuatan pidananya sesuai dengan peraturan perundang-undangan yang ada di Indonesia. Hal tersebut menyulitkan aparat penegak hukum dalam proses penanganannya karena kecanggihan modus operandi pelaku tersebut saat ini tidak dibarengi dengan pembaharuan peraturan yang ada, namun dalam prakteknya pada akhirnya ditempuh suatu kebijakan (yang merupakan diskresi aparat penegak hukum) dengan memfokuskan akibat eksploitasi seksual pada anak melalui internet tersebut dalam rangka upaya perlindungan hak-hak anak dengan melakukan pendekatan perundangan yaitu dapat dilakukan pendekatan perundangan pornografi, tanpa harus membuktikan unsur media internet dan pendekatan dengan perundangan Informasi Transaksi Elektronik, tanpa harus membuktikan unsur anak didalamnya. 


\section{Daftar Bacaan}

\section{Buku}

ECPAT, Eksploitasi Seksual Komersial Anak (Restu Printing 2002).

—_, 'Memerangi Pariwisata Sex Anak' (2008).

Eddy O.S. Hiariej, Prinsip-Prinsip Hukum Pidana. Yogyakarta (Cahaya Atma Pustaka 2014).

Hamzah A, Pengantar Hukum Acara Pidana Indonesia (Ghalia Indonesia 1985).

Moeljatno, Asas-Asas Hukum Pidana (Rineka Cipta 1983).

Peter Mahmud Marzuki, Penelitian Hukum, (Kencana Prenada Media Group 2005).

Ramli AM, Cyberlaw Dan HAKI Dalam Sistem Hukum Indonesia (Refika Aditama 2004).

Soemitro IS, Aspek Hukum Perlindungan Anak (Bumi Aksara 1990).

Sujamawardi LH, 'Analisis Yuridis Pasal 27 Ayat (1) Undang-Undang Nomor 19 Tahun 2016 Tentang Perubahan Atas Undang-Undang Nomor 11 Tahun 2008 Tentang Informasi Dan Transaksi Elektronik' (2018) 9.

Utamadi G dan PU, Pelecehan Seksual (2001).

\section{Jurnal}

Febri Dwi Yanto, 'Analisis Yuridis Ketentuan Pertanggungjawaban Pidana Bagi Pelaku Prostitusi Online Di Indonesia’ (2017) 1 Legal Spirit.

Nurman Syarif, 'Kekerasan Fisik Dan Seksual (Analisis Terhadap Pasal 5 A Dan C No. 23 UU PKDRT Tahun 2004 Ditinjau Dari Perspektif Hukum Islam)' (2012) 10 Al-'Adalah.[423-434].

Shofiyul Fuad Hakiki, 'Eksploitasi Jasa Anak Menurut Undang-Undang Nomor 23 Tahun 2002 Dan Hukum Pidana Islam’, (2017) 2 Al-Jinayah: Jurnal

Syarif artikel N, 'Kekerasan Fisik Dan Seksual (Analisis Terhadap Pasal 5 A Dan C No. 23 UU PKDRT Tahun 2004 Ditinjau Dari Perspektif Hukum Islam)' (2012) 10 Al-'Adalah. 


\section{Laman}

FNH, 'Perjelas Kompensasi Bagi Anak Korban Eksploitasi Seks : Anak Yang Menjadi Korban Eksploitasi Seksual Terus Bertambah' (Hukum Online.com) $<$ https://www.hukumonline.com/berita/baca/lt52b1218c35bc1/perjelaskompensasi-bagi-anak-korban-eksploitasi-seks> accessed 14 January 2019.

Tim ECPAT, 'Modul Eksploitasi Seksual Anak Di Ranah Online Untuk Anak' (Tim ECPAT, 2018) <https://www.slideshare.net/ecpatindonesia/moduleksploitasi-seksual-anak-online-ecpat-anak> accessed 12 February 2019.

United Nations Human Rights, 'Optional Protocol To The Convention On The Rights Of The Child On The Sale Of Children, Child Prostitution And Child Pornography' (United Nations Human Rights) <https://www.ohchr.org/en/ professionalinterest/pages/opsccrc.aspx $>$.

\section{Perundang-undangan}

Undang-Undang Dasar Negara Republik Indonesia Tahun 1945.

Undang-Undang Nomor 1 Tahun 1946 tentang Peraturan Hukum Pidana Jo Undang -undang Nomor 73 Tahun 1958 tentang Menyatakan Berlakunya Undang-undang Nomor 1 Tahun 1946 Republik Indonesia tentang Peraturan Hukum Pidana Untuk Seluruh Wilayah Republik Indonesia dan Mengubah Undang-undang Hukum Pidana (Lembaran Negara Nomor 127 Tahun 1958, Tambahan lembaran Negara Nomor 1660 Tahun 1958).

Undang-Undang Republik Indonesia Nomor 4 Tahun 1979 tentang Kesejahteraan Anak (Lembaran Negara Republik Indonesia Tahun 1974 Nomor 53, Tambahan Lembaran Negara Republik Indonesia Nomor 3039).

Undang-Undang Republik Indonesia Nomor 8 Tahun 1981 tentang Hukum Acara Pidana (Lembaran Negara Republik Indonesia Tahun 1981 Nomor 76).

Undang-Undang Republik Indonesia No.39 Tahun 1999 tentang Hak Asasi Manusia (Lembaran Negara Republik Indonesia Tahun 1999 Nomor 165).

Undang-Undang Republik Indonesia No. 13 Tahun 2006 tentang Perlindungan Saksi dan Korban (Lembaran Negara Republik Indonesia Tahun 2006 Nomor 64, Tambahan Lembaran Negara Republik Indonesia Nomor 4635)

Undang-Undang Republik Indonesia Nomor 21 Tahun 2007 tentang Pemberantasan Tindak Pidana Perdagangan Orang (Lembaran Negara Republik Indonesia Tahun 2007 Nomor 58, Tambahan Lembaran Negara Republik Indonesia Nomor 4720). 
Undang-Undang Republik Indonesia Nomor 44 tahun 2008 tentang Pornografi (Lembaran Negara Republik Indonesia Tahun 2008 Nomor 181, Tambahan Lembaran Negara Republik Indonesia Nomor 4928).

Undang-Undang Republik Indonesia Nomor 11 Tahun 2012 tentang Sistem Peradilan Pidana Anak (Lembaran Negara Republik Indonesia Tahun 2012 Nomor 153, Tambahan Lembaran Negara Republik Indonesia Nomor 165).

Undang-Undang Republik Indonesia Nomor 17 Tahun 2016 tentang Penetapan Peraturan Pemerintah Pengganti Undang-Undang Nomor 1 Tahun 2016 tentang Perubahan Kedua atas Undang-Undang Republik Indonesia Nomor 23 Tahun 2002 tentang Perlindungan Anak menjadi undang-undang (Lembaran Negara Republik Indonesia Tahun 2016 Nomor 237, tambahan Lembaran Negara Republik Indonesia Nomor 5946) Jo Undang-Undang Republik Indonesia Nomor 35 Tahun 2014 tentang Perubahan atas Undang-Undang Nomor 23 Tahun 2002 tentang Perlindungan Anak (Lembaran Negara Republik Indonesia Tahun 2014 Nomor 297, Tambahan Lembaran Negara Republik Indonesia Nomor 5606).

HOW TO CITE: Twenty Purandari, 'Pertanggungjawaban Hukum Pelaku Eksploitasi Seksual Pada Anak Melalui Internet' (2019) Vol. 2 No. 2 Media Iuris. 